\title{
PENGARUH TUNJANGAN KINERJA TERHADAP KINERJA PEGAWAI PADA DINAS PERTANIAN KABUPATEN MINAHASA
}

\author{
Jecqueline Fritzie Najoan \\ Lyndon R. J. Pangemanan \\ Ellen G. Tangkere
}

\begin{abstract}
This study aims to determine the effect of performance allowances on the performance of pagawai in Minahasa District Agricultural Office. This study was conducted from May to August 2017 from preparation to the writing of research reports. Data used in this research are primary data and secondary data. Primary data is collected by distributing questionnaires directly to employees for selfcompletion. The population in this study was all employees in Minahasa District Agriculture Office which amounted to 184 employees. Slovin formula is used to determine the number of samples so as to obtain the number of samples of 64 respondents. Data analysis techniques used are validity test, reliability test and simple linear regression analysis, for hypothesis testing using $t$-test with SPSS version 20 program. The research results showed that the test result $t$ probabilility value of $0.000<0.05$, which means $\mathrm{HO}$ rejected and $\mathrm{HI}$ accepted. Therefure, the performance allowances significantly influence the performance of employees in the Minahasa District Agricultural Office.
\end{abstract}

Keywords: influence of performance allowance, employee performance, Agriculture Department, Minahasa District.

\begin{abstract}
ABSTRAK
Penelitian ini bertujuan untuk mengetahui pengaruh tunjangan kinerja terhadap kinerja pegawai di Dinas Pertanian Kabupaten Minahasa. Penelitian ini dilaksanakan dari bulan Mei sampai bulan Agustus 2017 mulai dari persiapan sampai penulisan laporan penelitian. Data yang digunakan dalam penelitian ini adalah data primer dan data sekunder. Data primer dikumpulkan dengan cara membagikan kuesioner secara langsung kepada pegawai untuk diisi sendiri. Populasi dalam penelitian ini adalah seluruh pegawai di Dinas Pertanian Kabupaten Minahasa yang berjumlah 184 orang pegawai. Rumus Slovin digunakan untuk menentukan jumlah sample sehingga diperoleh jumlah sampel sebanyak 64 responden. Sedangkan data sekunder diperoleh dari Kantor Dinas Pertanian Kabupaten Minahasa. Teknik analisis data yang digunakan adalah uji validitas, uji reliabilitas dan analisis regresi linier sederhana, untuk pengujian hipotesis menggunakan uji-t dengan program SPSS versi 20. Hasil penelitian menunjukkan bahwa hasil uji-t nilai probabililitas sebesar $0,000<0,05$, yang berarti $\mathrm{H} 0$ ditolak dan $\mathrm{H} 1$ diterima. Dengan demikian tunjangan kinerja berpengaruh signifikan terhadap kinerja pegawai di Dinas Pertanian Kabupaten Minahasa.
\end{abstract}

Kata kunci: pengaruh tunjangan kinerja, kinerja pegawai, Dinas Pertanian, Kabupaten Minahasa. 


\section{PENDAHULUAN}

\section{Latar Belakang}

Perkembangan yang terjadi dalam perekonomian dunia semakin cepat dan sulit diprediksikan. Semakin canggih ilmu pengetahuan dan teknologi menuntut organisasi untuk berbenah diri menghadapi tantangan dan perubahan yang serba tidak terduga. Salah satu tantangan yang dihadapi dimasa depan adalah untuk menciptakan organisasi yang menuntut pengelolaan sumber daya yang efisien dan efektif agar bisa berkembang dalam persaingan yang semakin ketat. Suatu organisasi perlu melakukan upaya untuk mengelola apa yang dimilikinya, termasuk dengan pengelolaan sumber daya manusia yang menggambarkan bahwa kebutuhan akan sumber daya manusia yang bermutu tinggi akan semakin besar.

Potensi setiap sumber daya manusia yang ada dalam suatu organisasi harus dapat dimanfaatkan dengan sebaik-baiknya sehingga mampu memberikan hasil kerja yang optimal. Tercapainya tujuan yang telah ditetapkan suatu organisasi tidak hanya tergantung pada peralatan moderen, sarana dan prasarana yang lengkap, tetapi juga tergantung pada manusia yang melaksanakan pekerjaan tersebut. Keberhasilan suatu organisasi sangat besar dipengaruhi oleh kinerja individu pegawainya.

Kinerja pada dasarnya merupakan tanggung jawab dari setiap individu yang bekerja dalam institusi atau suatu organisasi. Kinerja yang baik adalah hasil pekerjaan optimal dan sesuai standar organisasi dan mendukung tercapainya tujuan organisasi. Peningkatan kinerja pegawai akan membawa kemajuan bagi instansi (organisasi) untuk dapat bertahan dalam suatu persaingan yang tidak stabil. Pencapaian kinerja pegawai yang optimal dapat dilihat dari kesejahteraan pegawai dan faktor-faktor yang mendukung kinerja pegawai. Sutrisno (2010), menyimpulkan kinerja pegawai adalah hasil kerja karyawan dilihat pada aspek kualitas, kuantitas, waktu kerja dan kerja sama untuk mencapai tujuan yang sudah ditetapkan bersama oleh organisasi.

Untuk meningkatkan efisiensi dan efektivitas instansi pemerintahan dalam pembangunan daerah terutama peningkatan kinerja pegawai perlu adanya motivasi agar pegawai bisa bekerja dengan baik dan maksimal salah satunya dengan dengan diberikannya tunjangan kinerja kepada pegawai negeri sipil yang dapat memacu semangat pegawai dalam melakasnakan tugas dan tanggung jawab atas pekerjaannya dengan cepat dan benar. Tunjangan Kinerja adalah salah satu faktor eksternal yang berpengaruh terhadap upaya peningkatan kinerja pegawai. Tunjangan kinerja merupakan salah satu implementasi pemberian kompensasi atau imbalan yang 1 ayak atas kinerja atau prestasi kerja. Atau dengan kata lain tunjangan kinerja adalah penghargaan berupa tambahan penghasilan yang di berikan kepada pegawai atas kinerjanya dengan tujuan untuk meningkatkan semangat kerja pegawai. Pemberian tunjangan kinerja menurut Peraturan Pemerintah Nomor 58 Tahun 2005 tentang Pengelolaan Keuangan Daerah pada Pasal 63 menegaskan "Tambahan Penghasilan diberikan dalam rangka meningkatan kesejahteraan pegawai berdasarkan prestasi kerja, tempat bertugas, kondisi kerja dan kelangkaan profesi". Tunjangan Kinerja diberikan kepada pegawai negeri sipil dan calon pegawai negeri sipil. Pemberian tunjangan kinerja kepada setiap pegawai di harapkan dapat mewujudkan penegakan disiplin dan dapat meningkatan kinerja pegawai dalam memberikan pelayanan kepada instansi dan masyarakat serta dapat meningkatkan kesejahteraan bagi pegawai negeri sipil di lingkungan Dinas Pertanian Kabupaten Minahasa.

Berikut ini adalah jumlah besaran tunjangan kinerja yang diterima oleh pegawai pada Dinas Pertanian Kabupaten Minahasa :

Tabel 1. TKD Dinas Pertanian Kabupaten Minahasa

\begin{tabular}{lc}
\hline \multicolumn{1}{c}{ Pangkat } & Tunjangan \\
\hline Eselon II b & Rp 15.000 .000 \\
Eselon III a & Rp 6.000 .000 \\
Eselon III b & Rp 5.000 .000 \\
Eselon IVa & Rp 2.500 .000 \\
Eselon IV b & Rp 2.000 .000 \\
Bendahara & Rp 2.500 .000 \\
Penyuluh Pertanian Gol IV & Rp 2.500 .000 \\
Penyuluh Pertanian Gol III & Rp 2.000 .000 \\
Penyuluh Pertanian Gol II & Rp 1.500 .000 \\
Staf & Rp 1.000 .000 \\
\hline Sumber : Dinas Pertanian di Kabupaten Minahasa, 2017
\end{tabular}

Sumber : Dinas Pertanian di Kabupaten Minahasa, 2017 
Tabel 1 menunjukkan tunjangan kinerja daerah (TKD) pegawai yang ada di Dinas Pertanian Kabupaten Minahasa. Pegawai dengan pangkat Eselon II b memiliki tunjangan kinerja yang lebih tinggi dari pegawai dibawahnya sementara pegawai dengan tunjangan kinerja paling rendah adalah Staf.

\section{Perumusan Masalah}

Berdasarkan latar belakang, maka yang menjadi rumusan masalah pada penelitian ini adalah apakah tunjangan kinerja berpengaruh terhadap kinerja pegawai di Dinas Pertanian Kabupaten Minahasa?

\section{Tujuan Penelitian}

Berdasarkan latar belakang penelitian dan permasalahan, maka tujuan yang ingin dicapai dalam penelitian ini adalah mengetahui pengaruh tunjangan kinerja terhadap kinerja pegawai di Dinas Pertanian, Kabupaten Minahasa.

\section{Manfaat Penelitian}

Hasil Penelitian ini diharapkan dapat memberikan manfaat antara lain:

\section{a. Manfaat Teoritis}

Sebagai sumbangan bagi ilmu pengetahuan yang menyangkut manajemen sumber daya manusia lebih khusus tentang tunjangan kinerja dan kinerja pegawai.

b. Manfaat Praktis

1. Bagi Peneliti, dapat melatih cara berpikir, menganalisis data, dan menambah pengalaman serta penelitian ini merupakan salah satu syarat untuk memperoleh gelar sarjana di Fakultas Pertanian Universitas Sam Ratulangi Manado.

2. Bagi objek penelitian, hasil penelitian ini diharapkan dapat memberikan informasi yang membantu penerapan pemberian tunjangan kinerja yang efektif sehingga dapat meningkatkan kinerja pegawai.

3. Bagi peneliti lain, hasil penelitian ini dapat digunakan sebagai bahan acuan untuk penelitian selanjutnya sesuai dengan topik penelitian.

\section{METODOLOGI PENELITIAN}

\section{Waktu dan Tempat Penelitian}

Penelitian ini dilakukan di Kantor Dinas Pertanian Kabupaten Minahasa yang bertempat di Jln. Maesa No. 153 Sasaran Tondano Sulawesi Utara. Waktu penelitian dilakukan selama 3 bulan dimulai pada bulan Mei 2017 sampai dengan bulan Agustus 2017.

\section{Jenis dan Sumber Data}

Data yang digunakan dalam penelitian ini adalah data primer dan data sekunder. Data primer yaitu data yang diperoleh dengan cara membagikan kuesioner secara langsung kepada pegawai. Sedangkan data sekunder adalah data yang diperoleh dari data yang telah tersusun dalam bentuk dokumen tertulis dari Dinas Pertanian Kabupaten Minahasa, literatur terdahulu maupun di internet.

\section{Metode Pengumpulan Data}

Data yang digunakan dalam penelitian ini adalah data primer yang bersifat kuantitatif, dimana instrumen utamanya adalah kuesioner yang berisi pernyataan menyangkut tunjangan kinerja dan kinerja pegawai yang diberikan kepada pegawai terpilih untuk diisi secara benar dan jujur.

\section{Populasi dan Sampel}

Populasi adalah keseluruhan objek penelitian (Arikunto, 2006). Adapun populasi dalam penelitian ini adalah seluruh pegawai Dinas Pertanian Kabupaten Minahasa yang berjumlah 184 orang pegawai. Sampel adalah sebagian dari jumlah dan karakteristik yang dimiliki oleh populasi tersebut (Sugiyono, 2008). Jumlah sampel dalam penelitian ini adalah 64 responden dengan menggunakan rumus slovin yaitu sebagai berikut:

$$
\boldsymbol{n}=\frac{\boldsymbol{N}}{\mathbf{1}+\boldsymbol{N} \boldsymbol{e}^{\mathbf{2}}} \boldsymbol{n}=\frac{185}{1+185(10 \%)^{2}} n=64
$$

$\mathrm{n}$ adalah ukuran sampel, $\mathrm{N}=$ ukuran populasi, e = tingat kesalahan dalam persen atau toleransi ketidaktelitian dalam menentukan banyaknya responden. 
Untuk pengambilan sampel dilakukan secara proportional random sampling dengan memakai rumus alokasi proportional sebagai berikut:

$$
n_{i}=\frac{N_{i}}{N} n
$$

$\mathrm{n}_{\mathrm{i}}$ adalah jumlah sampel menurut stratum, $\mathrm{n}=$ jumlah sampel seluruhnya, $\mathrm{N}_{\mathrm{i}}=$ jumlah populasi menurut stratum, $\mathrm{N}=$ jumlah populasi.

Atas dasar perhitungan tersebut didapatkan hasil mengenai jumlah sampel pada setiap jabatan kerja organisasi, dapat dilihat pada Tabel 2.

Tabel 2. Data Sampel Penelitian

\begin{tabular}{clcc}
\hline No. & \multicolumn{1}{c}{ Jabatan } & Populasi & Sampel \\
\hline 1. & Kepala Dinas & 1 Pegawai & 1 Pegawai \\
2. & Sekretaris & 1 Pegawai & 1 Pegawai \\
3. & Kepala Sub Bagian & 3 Pegawai & 1 Pegawai \\
4. & Kepala Bidang & 6 Pegawai & 2 Pegawai \\
5. & Kepala Seksie & 18 Pegawai & 6 Pegawai \\
6. & Kepala UPTD & 25 Pegawai & 8 Pegawai \\
7. & Penyuluh Pertanian & 103 Pegawai & 35 Pegawai \\
8. & Staf & 29 Pegawai & 10 Pegawai \\
\hline & Jumlah & 185 Pegawai & 64 Pegawai \\
\hline
\end{tabular}

Sumber: Dinas Pertanian Kabupaten Minahasa, 2017

Untuk kuesioner tunjangan kinerja dinilai/diisi oleh pegawai sendiri dan untuk kuesioner penilaian kinerja pegawai dinilai/diisi oleh atasan dibagi menjadi empat bagian yaitu Kepala Dinas menilai 11 orang pegawai, Sekretaris menilai 1 orang pegawai, Kepala Bidang menilai 16 orang pegawai dan Kepala UPTD menilai 35 orang pegawai berdasarkan sampel penelitian.

\section{Konsep dan Pengukuran Variabel}

I. Karakteristik responden mencakup:

a. Jenis kelamin : (Laki-laki/Perempuan)

b. Usia : jumlah tahun responden saat ini

c. Tingkat pendidikan : pendidikan terakhir responden

d. Masa kerja (Lama kerja)
Variabel yang di ukur dalam penelitian ini yaitu tunjangan kinerja $(\mathrm{X})$ dan kinerja karyawan (Y). Berikut ini adalah definisi operasional dari variabel tersebut:

1. Tunjangan Kinerja (X)

Tunjangan Kinerja adalah tunjangan yang diberikan kepada Pegawai Negeri Sipil yang merupakan fungsi dari keberhasilan pelaksanaan reformasi birokrasi. Indikatornya sebagai berikut:

a. Penerimaan tunjangan sesuai aturan pemerintah daerah;

b. Tunjangan yang diterima menambah penghasilan pegawai;

c. Ketepatan waktu menerima tunjangan kinerja;

d. Tingkat kecukupan dalam memenuhi kebutuhan pegawai;

e. Penerimaan tunjangan sesuai dengan kedisiplin pegawai.

2. Kinerja Pegawai (Y)

Kinerja Pegawai adalah hasil kerja secara kualitas dan kuantitas yang dicapai oleh seorang pegawai dalam melaksanakan tugasnya sesuai dengan tanggung jawab yang diberikan kepadanya. Indikatornya menurut Mitchel dalam Sedarmayanti (2001) adalah sebagai berikut:
a. Kuantitas pekerjaan
b. Ketepatan waktu
c. Inisiatif
d. Kemampuan
e. Komunikasi

\section{Skala Pengukuran Variabel dan Uji Instrumen Penelitian}

\section{Skala Pengukuran Variabel}

Dalam melakukan pengukuran atas jawaban dari kuesioner-kuesioner penelitian yang diajukan kepada responden, skala yang digunakan adalah skala likert. Skala Likert digunakan untuk mengukur sikap, pendapat, persepsi seseorang atau sekelompok orang tentang fenomena sosial, Sugiono (2011). Berikut ini adalah skor yang digunakan untuk setiap jawaban skala likert: 
Tabel 3. Skor untuk Jawaban Skala Likert

\begin{tabular}{clc}
\hline No & \multicolumn{1}{c}{ Keterangan } & Skor \\
\hline 1 & Sangat Setuju & 5 \\
2 & Setuju & 4 \\
3 & Netral & 3 \\
4 & Tidak Setuju & 2 \\
5 & Sangat Tidak Setuju & 1 \\
\hline
\end{tabular}

Sumber: Sugiyono, 2011

\section{Uji Instrumen Penelitian (Kuesioner Penelitian)}

Peneliti melakukan penggujian instrumen penelitian terlebih dahulu sebelum melakukan penelitian yang sebenarnya. Uji coba terhadap kuesioner tersebut digunakan untuk mengetahui validitas dan reliabilitas suatu kuesioner penelitian

\section{Uji Validitas Kuesioner Penelitian}

Sebelum instrumen penelitian digunakan untuk mengumpulkan data perlu dilakukan pengujian validitas. Hal ini digunakan untuk mendapatkan data yang valid dari instrumen yang valid atau untuk mengukur apakah kuesioner layak dijadikan instrumen penelitian pengujian instrumen dalam penelitian ini dilakukan dengan korelasi bivariate antara masing-masing skor indikator dengan total skor konstruk (pearson correlation) (Sugiyono, 2012). Kriteria uji valid dengan korelasi bivariate adalah sebagai berikut :

- Jika Nilai sig < alpha $(0,05)$ maka suatu instrument dinyatakan valid.

- Jika Nilai sig > alpha $(0,05)$ maka suatu instrument dinyatakan tidak valid.

\section{Uji Reliabilitas Kuesioner Penelitian}

Uji reliabilitas merupakan alat untuk mengukur suatu kuesioner yang merupakan indikator dari variabel atau konstruk. Instrumen yang reliabel adalah instrumen yang bila digunakan beberapa kali untuk mengukur obyek yang sama, akan menghasilkan data yang sama. Adapun pengukuran reliabilitas dapat dilakukan dengan cara yaitu One Shot atau pengukuran sekali aja disini pengukurannya hanya sekali dan kemudian hasilnya dibandingkan dengan pertanyaan lain atau pengukur korelasi antar jawaban pertanyaan (Ghozali, 2011). Kriteria uji reliabilitas adalah sebagai berikut :

- Jika nilai Cronbach Alpha > 0,6 maka suatu instrumen dinyatakan reliable.

- Jika nilai Cronbach Alpha < 0,6 maka suatu instrumen dinyatakan tidak reliable.

\section{Teknik Analisis Data}

Teknik analisis data yang digunakan dalam penelitian ini adalah analisis regresi linier sederhana yang bertujuan untuk melihat pengaruh tunjangan kinerja terhadap kinerja pegawai di Dinas Pertanian Kabupaten Minahasa.

\section{Analisis Regresi Linier Sederhana}

Analisis regresi linier sederhana adalah hubungan secara linier antara satu variabel independen (X) dengan variabel dependen (Y). Analisis ini untuk mengetahui arah hubungan variabel independen dengan variabel dependen apakah positif atau negatif dan untuk memprediksikan nilai variabel independen mengalami kenaikan atau penurunan. Secara matematis bentuk persamaan dari regresi linier sederhana adalah sebagai berikut:

$$
\mathbf{Y}=\mathbf{a}+\mathbf{b X}+\mathbf{e}
$$

$\mathrm{Y}$ adalah kinerja pegawai, $\mathrm{a}=$ konstanta, $\mathrm{b}=$ koefisien regresi, $\mathrm{X}=$ tunjangan kinerja, e = error.

\section{Uji Hipotesis}

Hipotesis yang digunakan untuk pengaruh secara parsial yaitu hipotesis $t$. Langkah-langkah dalam pengujian hipotesis ini dimulai dengan menetapkan hipotesis nol (H0) dan hipotesis alternatif (Ha), pemilihan tes statistik dan perhitungan nilai statistik, penetapan tingkat signifikasi dan penetapan 
kriteria pengujian. Rumusan hipotesisnya adalah sebagai berikut:

1. H0 : $\rho=0$, berarti variabel bebas $(X)$ tidak berpengaruh terhadap variabel terikat $(\mathrm{Y})$.

2. H1: $\rho \neq 0$, berarti variabel bebas $(X)$ berpengaruh terhadap variabel terikat.

Jika:

- Nilai signifikan > 0,5 maka Ho diterima dan $\mathrm{H} 1$ di tolak atau tunjangan kinerja tidak berpengaruh signifikan erhadap kinerja pegawai.

- Nilai signifikan < 0.5 maka Ho ditolak dan H1diterima atau tunjangan kinerja berpengaruh signifikan terhadap kinerja pegawai.

\section{HASIL DAN PEMBAHASAN}

\section{Gambaran Umum Dinas Pertanian Kabupaten Minahasa}

Dinas Petanian adalah unsur pelaksana daerah untuk memberikan pelayanan administrasi dan teknis kepada masyarakat sesuai dengan tugas dan fungsinya yang dipimpin oleh Kepala Dinas yang berkedudukan dibawah, dalam pelaksanaan tugas secara teknis administratif bertanggung jawab kepada Bupati melalui Sekretaris Daerah. Dinas Pertanian Kabupaten Minhasa sebagai salah satu Satuan Kerja Perangkat Dareah (SKPD) di kabupaten Minahsa yang mempunyai tugas membantu Bupati melaksanakan urusan pemerintahan yang menjadi kewenangan daerah dan tugas pembantuan di bidang pertanian. Dinas Pertanian ini dibentuk berdasarkan Peraturan Daerah Kabupaten Minahasa Nomor 4 Tahun 2016 tentang Pembentukan dan Susunan Daerah Kabupaten Minahasa.

Dinas Pertanian dipimpin oleh Kepala Dinas dan membawahi 1 Sekretariat, 3 Sub Bagian, 6 Bidang, 18 Seksi, 25 Kepala UPTD Pertanian (unit pelaksana teknis dinas) dan 25 Sub bagian Tata Usaha UPTD (unit pelaksana teknis dinas) yakni:

1. Kepala Dinas membawahi;

2. Sekretariat Dinas, membawahi tiga sub bagian yaitu :
a. Sub bagian Perencanaan dan Evaluasi;
b. Sub bagian Keuangan dan Asset;
c. Sub bagian Umum dan Kepegawaian.

3. Bidang Prasarana dan Sarana, membawahi tiga seksi, yaitu :
a. Seksi Lahan dan Irigasi;
b. Seksi Pupuk,Pestisida dan Alsintan;
c. Seksi Pembiayaan dan Investasi.

4. Bidang Tanaman Pangan, membawahi tiga seksi, yaitu :
a. Seksi Perbenihan dan Perlindungan;
b. Seksi Produksi;
c. Seksi Pengolahan dan Pemasaran

5. Bidang Hortikultura, membawahi tiga seksi, yaitu :
a. Seksi Perbenihan dan Perlindungan;
b. Seksi Produksi;
c. Seksi Pengolahan dan Pemasaran

6. Bidang Perkebunan, membawahi tiga seksi, yaitu :
a. Seksi Perbenihan dan Perlindungan;
b. Seksi Produksi;
c. Seksi Pengolahan dan Pemasaran

7. Bidang Peternakan dan Kesehatan Hewan, membawahi tiga seksi, yaitu :
a. Seksi Perbibitan dan Produksi;
b. Seksi Kesehatan Hewan;
c. Seksi Kesmavet, Pengolahan dan Pemasaran

8. Bidang Penyuluhan, membawahi tiga seksi, yaitu :
a. Seksi Kelembagaan;
b. Seksi Ketenagaan;
c. Seksi Metode dan Informasi

9. Unit Pelaksana Teknis Dinas (UPTD) Penyuluhan Pertanian pada 25 Kecamatan masing-masing membawahi satu Sub Bagian Tata Usaha.

10. Kelompok Jabatan Fungsional, yaitu :

a. KJF Penyuluh Pertanian;

b. KJF Pengendali Organisme Penganggu Tumbuhan dan Pengawas Benih Tanaman;

c. KJF Pengawas Bibit Ternak, Medik Veteriner, Paramedik Veteriner dan Pengawas Mutu Pakan;

d. KJF Pengawas Mutu Hasil Pertanian, dan Analisa Pasar Hasil Pertanian. 


\section{Fungsi Dinas Pertanian Kabupaten Minahasa}

Dinas Pertanian Kabupaten Minahasa memiliki fungsi sebagai berikut:

a. Perumusan kebijakan dibidang prasarana dan sarana, tanaman pangan, hortikultura, perkebunan, peternakan dan kesehatan hewan serta penyuluhan pertanian;

b. Penyusunan program penyuluhan pertanian;

c. Pengembangan prasarana pertanian;

d. Pengawasan mutu, peredaran dan pengendalian penyediaan benih tanaman, benih atau bibit ternak dan hijauan pakan ternak;

e. Pengawasan pengunaan sarana pertanian;

f. Pembinaan produksi dibidang pertanian;

g. Pengendalian dan penanggulangan hama penyakit tanaman dan penyakit hewan;

h. Pengendalian dan penanggulangan bencana alam;

i. Pembinaan dan pengolahan hasil pertanian;

j. Pelaksanaan penyuluhan pertanian;

k. Pemberian izin usaha atau rekomendasi teknis pertanian;

1. Pemantauan dan evaluasi dibidang pertanian;

m. Pelaksanaan administrasi Dinas Pertanian;

n. Pelaksanaan fungsi lain yang diberikan oleh Bupati sesuai dengan tugas dan fungsinya.

\section{Visi dan Misi Dinas Pertanian Kabupaten Minahasa}

a. Visi Dinas Pertanian MInahasa

"Terwujudnya pertanian berbasis agribisnis menuju masyarakat Minahasa sejahtera yang bermatabat tahun 2018".

b. Misi Dinas Pertanian Minahasa

- Menciptakan penyelenggaraan pembangunan pertanian yang berorientasi agribisnis dengan memanfaatkan potensi-potensi sumber daya alam secara berkelanjutan dan berwawasan lingkungan. Meningkatkan peran serta masyarakat pertanian dalam mendukung pembangunan sistem dan usaha agribisnis yang produktif, efisien dan efektif.

- Meningkatkan produktifitas dan mutu produk-produk unggulan pertanian yang mampu bersaing di pasar global.

- Meningkatkan kualitas sumberdaya manusia pertanian yang berorientasi pencapaian kinerja dengan memiliki budaya etos kerja "Mapalus" dan "Si Tоu Timou Tumou Tou".

\section{Karakteristik Responden}

Reponden yang digunakan dalam penelitian ini merupakan pegawai yang bekerja pada Dinas Pertanian Kabupaten Minahasa yang ditemui di Kantor Dinas Pertanian dan Unit Pelaksana Teknis Dinas (UPTD) Pertanian yang berjumlah 64 orang. Karakteristik responden yang digunakan adalah jenis kelamin, usia, pendidikan dan masa kerja yang dimaksudkan untuk melihat pola sebaran responden.

\section{Karakteristik Responden Berdasarkan Jenis Kelamin}

Berdasarkan hasil penelitian diperoleh karakteristik responden berdasarkan jenis kelamin dapat dilihat pada Tabel 4.

Tabel 4. Karakteristik Responden Berdasarkan Jenis Kelamin

\begin{tabular}{lcc}
\hline \multicolumn{1}{c}{ Keterangan } & Jumlah & Persentase \\
\hline Laki-laki & 33 & 51,56 \\
Perempuan & 31 & 48,44 \\
\hline Total & 64 & 100 \\
\hline
\end{tabular}

Sumber : Diolah dari Data Primer, 2017

Tabel 4 menunjukkan jumlah responden yang ada di Dinas Pertanian Kabupaten Minahasa berdasarkan jenis kelamin. Sebagian besar pegawai yang bekerja adalah yang berjenis kelamin laki-laki sebanyak 33 orang dengan presentase $51,56 \%$ sedangkan responden perempuan sebanyak 31 orang 
dengan presentase $48,44 \%$ dari total seluruh responden.

\section{Karakteristik Responden Berdasarkan Usia}

Berdasarkan hasil penelitian diperoleh karakteristik responden pegawai berdasarkan usia dapat dilihat pada Tabel 5.

\section{Tabel 5. Karakteristik Responden Berdasarkan Usia}

\begin{tabular}{lcc}
\hline Keterangan & Jumlah & Persentase \\
\hline 21-30 Tahun & 0 & 0 \\
31-40 Tahun & 17 & 26,56 \\
$>$ 40 Tahun & 47 & 73,44 \\
\hline Total & 64 & 100
\end{tabular}

Sumber : Diolah dari Data Primer, 2017

Tabel 5 menunjukkan responden yang bekerja di Dinas Pertanian Kabupaten Minahasa berdasarkan pengelompokan Usia. Responden dengan usia 21-31 tahun sebanyak 0 . Respoden dengan usia 31-40 tahun sebanyak 17 orang dengan persentase $26,56 \%$ dan respoden dengan usia > 40 tahun berjumlah 47 orang dengan persentase $73,44 \%$. Dari data tersebut menunjukkan bahwa responden dengan usia > 40 tahun adalah yang paling banyak berdasarkan total seluruh responden.

\section{Karakteristik Responden Berdasarkan Pendidikan}

Pendidikan dapat menambah wawasan pengetahuan dan kemampuan dalam diri seseorang. Begitu pula dalam suatu organisasi atau perusahaan pendidikan merupakan hal yang penting dalam menghasilkan sumber daya manusia yang kompeten dan berkualitas, sehingga dapat memberikan keuntungan tidak hanya bagi diri sendiri tetapi juga bagi organisasi atau perusahaan tempat bekerja.

Berikut ini adalah karakteristik responden yang ada di Dinas Pertanian Kabupaten Minahasa berdasarkan pendidikan:

\section{Tabel 6. Karakteristik Responden Berdasarkan Pendidikan}

\begin{tabular}{lcc}
\hline \multicolumn{1}{c}{ Keterangan } & Jumlah & Peresentase \\
\hline SMA & 22 & 34,38 \\
D3 & 0 & 0 \\
S1 & 41 & 64,06 \\
S2 & 1 & 1,56 \\
S3 & 0 & 0 \\
\hline Total & 64 & 100 \\
\hline Sur
\end{tabular}

Sumber : Diolah dari Data Primer, 2017

Tabel 6 menunjukkan responden berdasarkan pendidikan. Responden dengan tingkat pendidikan SMA sebanyak 22 orang dengan persentase $34,38 \%$, responden dengan pendidikan D3 sebanyak 0, responden dengan pendidikan S1 sebanyak 41 orang dengan persentase $64,06 \%$, responden dengan tingkat pendidikan S2 sebanyak 1 orang dengan persentase $1,56 \%$ dan responden dengan tingkat pendidikan S3 sebanyak 0. Berdasarkan hasil penelitian dapat dilihat bahwa responden yang berpendidikan $\mathrm{S} 1$ adalah yang paling banyak, hasil tersebut mengindikasikan bahwa dengan pendidikan S1, pegawai memiliki tingkat pengetahuan yang tinggi akan pekerjaan sesuai dengan jenjang sehingga dalam melaksanakan pekerjaan mereka akan melakukan dengan maksimal sesuai dengan bekal pengetahuan yang mereka miliki.

\section{Karakteristik Responden Berdasarkan Masa Kerja}

Masa kerja erat kaitannya dengan disiplin pegawai. Sedangkan disiplin mempunyai hubungan dengan kinerja pegawai. Berdasarkan hasil penelitian diperoleh karakteristik responden pegawai berdasarkan masa kerja dapat dilihat pada Tabel 7.

Tabel 7. Karakteristik Responden Berdasarkan Masa Kerja

\begin{tabular}{lcc}
\hline \multicolumn{1}{c}{ Keterangan } & Jumlah & Persentase \\
\hline$<5$ Tahun & 0 & 0 \\
5-10 Tahun & 18 & 28,125 \\
$>$ 10 Tahun & 46 & 71,875 \\
\hline Total & 64 & 100 \\
\hline
\end{tabular}

Sumber : Diolah dari Data Primer, 2017 
Tabel 7 menunjukkan responden berdasarkan masa kerja. Responden dengan masa kerja $<5$ tahun sebanyak 0, responden dengan masa kerja 5-10 tahun sebanyak 18 orang dengan persentase $28,125 \%$ dan responden dengan masa kerja 10 tahun sebanyak 46 orang dengan persentase $71,875 \%$. Dengan pegawai yang didominasi masa kerja yang lama akan mendapatkan mutu kerja yang lebih baik dari sebelumnya, karena umumnya pegawai dengan masa kerja yang lama lebih memahami manajemen pola kerja yang diterapkan dalam suatu organisasi.

\section{Deskripsi Jawaban Respoden}

\section{Deskripsi Jawaban Responden Pada Variabel Tunjangan Kinerja (X)}

Tunjangan kinerja yang diterapkan di Dinas Pertanian Kabupaten Minahasa merupakan upaya yang dilakukan pemerintah untuk meningkatkan kinerja dan kesejahteraan para pegawai. Pemberian tunjangan kinerja yang tidak adil akan menimbulkan berbagai masalah yaitu adanya pegawai yang tidak disiplin waktu pada saat jam datang dan pulang kerja dengan semaunya sendiri, pekerjaan yang tidak selesai sesuai kesepakatan bersama. Berdasarkan hasil penelitian diperoleh deskripsi jawaban responden pada variabel tunjangan kinerja atas 5 pernyataan yang dibagikan kepada 64 responden yang ada di Dinas Pertanian Kabupaten Minahasa, dapat dilihat pada Tabel 8 .

Tabel 8. Deskripsi Jawaban Responden pada Variabel Tunjangan Kinerja

\begin{tabular}{|c|c|c|c|c|c|c|c|}
\hline \multirow[t]{3}{*}{ No } & \multirow[t]{3}{*}{ Pernyataan } & \multicolumn{5}{|c|}{ Likert } & \multirow[t]{3}{*}{ Total } \\
\hline & & STS & TS & $\mathrm{N}$ & $\mathrm{S}$ & SS & \\
\hline & & $\%$ & $\%$ & $\%$ & $\%$ & $\%$ & \\
\hline 1 & $\begin{array}{l}\text { Tunjangan kinerja yang di } \\
\text { terima sudah sesuai dengan } \\
\text { aturan yang di tetapkan oleh } \\
\text { pemerintah daerah }\end{array}$ & 4,7 & 4,7 & 9,4 & 45,3 & 35,9 & 100 \\
\hline 2 & $\begin{array}{l}\text { Tunjangan kinerja yang diterima } \\
\text { dapat membantu menambah } \\
\text { penghasilan saya sebagai } \\
\text { pegawai negeri sipil }\end{array}$ & 0 & 0 & 4,7 & 39,1 & 56,3 & 100 \\
\hline 3 & $\begin{array}{l}\text { Tunjangan kinerja sudah rutin } \\
\text { diterima pegawai setiap bulan }\end{array}$ & 0 & 3,1 & 9,4 & 54,7 & 32,8 & 100 \\
\hline 4 & $\begin{array}{l}\text { Tunjangan kinerja yang diterima } \\
\text { saat ini sudah dapat memenuhi } \\
\text { kebutuhan hidup }\end{array}$ & 4,7 & 15,6 & 28,1 & 35,9 & 15,6 & 100 \\
\hline 5 & $\begin{array}{l}\text { Tunjangan kinerja yang diterima } \\
\text { sudah setara dengan kedisiplinan } \\
\text { pegawai }\end{array}$ & 0 & 6,3 & 20,3 & 53,1 & 20,3 & 100 \\
\hline
\end{tabular}

Tabel 8 menunjukkan deskripsi jawaban responden pada variabel Tunjangan Kinerja (X). Pada pernyataan Tunjangan Kinerja yang diterima sudah sesuai dengan aturan yang di tetapkan oleh pemerintah daerah responden menjawab paling banyak setuju dengan jumlah $45,3 \%$, hal tersebut karena responden menganggap tunjangan kinerja yang diberikan sudah sesuai dengan pekerjaan serta jabatan dari masing-masing pegawai. Pada pernyataan tunjangan kinerja yang diterima dapat membantu menambah penghasilan saya sebagai pegawai responden paling banyak menjawab sangat setuju dengan jumlah 56,3\%. Hal tersebut dikarenakan pegawai merasa gaji pokok yang mereka terima sedikit, sehingga pemberian tunjangan kinerja sangat membantu pegawai dalam menambah penghasilan. Pada pernyataan tunjangan kinerja sudah rutin diterima pegawai setiap bulan responden paling banyak menjawab setuju dengan jumlah $54,7 \%$. Hal tersebut dikarenakan tidak adanya keterlambatan pembayaran tunjangan setiap bulannya, kalaupun ada keterlambat itu disebabkan karena tanggal merah atau hari libur karena pembayaran tunjangan kinerja dilakukan secara langsung di kantor Dinas Pertanian Kabuapaten Minahasa melalui Bendahara. Pada pernyataan tunjangan kinerja yang diterima saat ini sudah dapat memenuhi kebutuhan hidup (kebutuhan keluarga, pendidikan anak, kesehatan dll) responden menjawab paling banyak setuju dengan jumlah $35,9 \%$ karena, tunjangan yang diberikan dapat membantu memenuhi kebutuhan hidup dari masing-masing pegawai. Pada pernyataan tunjangan kinerja yang diterima sudah setara dengan kedisiplinan pegawai, responden paling banyak menjawab setuju. Hal tersebut dikarenakan tunjangan yang diterima sudah sesuai dengan kedisiplinan pegawai berdasarkan presensi dan komponen disiplin pegawai. Dari hasil penelitian dapat dilihat bahwa tunjangan kinerja memberikan pengaruh dalam meningkatkan kinerja pegawai. Dengan pemberian tunjangan kinerja dapat memotivasi pegawai untuk lebih semangat dalam bekerja sehingga, pekerjaanya akan lebih optimal dibandingkan sebelum menerima tunjangan kinerja. 
..(Jecqueline Najoan, Lyndon Pangemanan, Ellen Tangkere)

\section{Deskripsi Jawaban Responden Pada Variabel Kinerja Pegawai (Y)}

Deskripsi jawaban responden tentang variabel kinerja pegawai yang didasarkan pada jawaban responden atas 12 pernyataan yang meliputi lima 5 indikator yaitu kualitas pekerjaan, ketepatan waktu, inisiatif, kemampuan dan komunikasi yang terdapat dalam kuesioner yang dibagikan kepada 64 responden. yang ada di Dinas Pertanian Kabupaten Minahasa.

Tabel 9. Deskripsi Jawaban Responden pada Indikator Kualitas Pekerjaan

\begin{tabular}{lllccccc}
\hline \multirow{2}{*}{ No } & \multicolumn{1}{c}{ Pernyataan } & \multicolumn{5}{c}{ Likert } & Total \\
\cline { 2 - 6 } & & STS & TS & N & S & SS & \\
$\%$ & $\%$ & $\%$ & $\%$ & $\%$ & \\
\hline 1 & $\begin{array}{l}\text { Dalam bekerja bawahan } \\
\text { selalu memeriksa kembali } \\
\text { hasil pekerjaan yang } \\
\text { dikerjakan }\end{array}$ & 1,6 & 7,8 & 4,7 & 46,9 & 39,1 & 100 \\
$\begin{array}{l}\text { Bawahan mengutamakan } \\
\text { kerapihan dalam } \\
\text { mengerjakan setiap }\end{array}$ & 0 & 0 & 4,7 & 56,3 & 39,1 & 100 \\
pekerjaan & & & & & & & \\
\hline Sumber : Data olahan SPSS 20,2017 & & & & & & \\
\hline
\end{tabular}

Tabel 9 menunjukkan deskripsi jawaban responden pada indikator Kualitas Pekerjaan. Pada pernyataan dalam bekerja bawahan selalu memeriksa kembali hasil pekerjaan yang dikerjakan responden paling banyak menjawab setuju dengan jumlah 46,9\%, karena pegawai/bawahan selalu berusaha untuk memeriksa kembali pekerjaanya dengan teliti sehingga dapat meminimalisir kesalahan-kesalahan yang dapat terjadi. Pada pernyataan bawahan mengutamakan kerapihan dalam mengerjakan setiap pekerjaan responden paling banyak menjawab setuju dengan jumlah 56,3\%, hal tersebut dikarena pimpinan selalu memeriksa setiap hasil pekerjaan dari masing-masing pegawai/bawahan sehingga membuat pegawai untuk lebih teliti dan rapih dalam melakukan tugas dan pekerjaanya. Berdasarkan penilaian maka kinerja pegawai dilihat dari indikator kualiatas pekerjaan dikategorikan baik, dibuktikan dengan banyaknya responden yang menjawab setuju. Dimana kualitas suatu pekerjaan dapat dilihat dari ketelitian dan kerapihan pegawai dalam memberikan hasil kerjayang yang baik.
Tabel 10. Deskripsi Jawaban Responden pada Indikator Ketepatan Waktu

\begin{tabular}{lllccccc}
\hline \multirow{2}{*}{ No } & \multicolumn{1}{c}{ Pernyataan } & \multicolumn{5}{c}{ Likert } & Total \\
\cline { 3 - 7 } & & STS & TS & N & S & SS & \\
& $\%$ & $\%$ & $\%$ & $\%$ & $\%$ & \\
\hline 1 & $\begin{array}{l}\text { Bawahan selalu tiba di } \\
\text { kantor tepat waktu }\end{array}$ & 0 & 9,4 & 12,5 & 50 & 28,1 & 100 \\
2 & $\begin{array}{l}\text { Bawahan berusaha tidak } \\
\text { menunda-nundapekerjaan }\end{array}$ & 0 & 4,7 & 12,5 & 51,6 & 31,3 & 100 \\
\hline
\end{tabular}

Sumber : Data olahan SPSS 20, 2017

Tabel 10 menunjukkan deskripsi jawaban responden pada indikator ketepatan waktu. Pada pernyataan bawahan selalu tiba di kantor tepat waktu responden menjawab paling banyak setuju dengan jumlah 50\%, dikarenakan setiap pagi pegawai diharuskan untuk mengikuti apel jika tidak pegawai akan dikenakan sanksi atau pengurangan poin kehadiran yang akan mempengaruhi besaran penerimaan tunjangan kinerja. Pada pernyataan bawahan berusaha tidak menunda-nunda pekerjaan responden paling banyak menjawab setuju dengan jumlah $51,6 \%$. Hal tersebut dikarenakan setiap pegawai selalu berusaha mengingatkan agar tidak menunda-nunda pekerjaan sehingga pekerjaan bisa diselesaikan dengan cepat sesuai dengan waktu yang ditentukan.

Tabel 11. Deskipsi Jawaban Responden pada Indikator Inisiatif

\begin{tabular}{|c|c|c|c|c|c|c|c|}
\hline \multirow[t]{3}{*}{ No } & \multirow[t]{3}{*}{ Pernyataan } & \multicolumn{5}{|c|}{ Likert } & \multirow[t]{3}{*}{ Total } \\
\hline & & STS & TS & $\mathrm{N}$ & $\mathrm{S}$ & SS & \\
\hline & & $\%$ & $\%$ & $\%$ & $\%$ & $\%$ & \\
\hline 1 & $\begin{array}{l}\text { Bawahan berusaha belajar } \\
\text { dan mencari informasi } \\
\text { tentang apapun yang } \\
\text { berkaitan dengan pekerjaan }\end{array}$ & 0 & 3,1 & 10,9 & 43,8 & 42,2 & 100 \\
\hline 2 & $\begin{array}{l}\text { Bawahan berusaha bekerja } \\
\text { tanpa menunggu perintah } \\
\text { dari atasan }\end{array}$ & 0 & 3,1 & 7,8 & 67,2 & 21,9 & 100 \\
\hline
\end{tabular}

Tabel 11 menunjukkan deskripsi jawaban responden pada indikator inisiatif. Pada pernyataan bawahan berusaha belajar dan mencari informasi tentang apapun yang berkaitan dengan pekerjaan responden paling banyak menjawab setuju dengan jumlah $43,8 \%$. Hal tersebut dikarenakan pegawai dituntut untuk aktif dalam bekerja. Dengan belajar dan mencari informasi yang berkaitan dengan pekerjaan akan membantu pegawai dalam menyelesaikan dan mengatasi kesulitan yang ditemui dalam pekerjaan. Pada pernyataan 
bawahan berusaha bekerja tanpa menunggu perintah dari atasan responden paling banyak menjawab setuju dengan jumlah $67,2 \%$. Hal tersebut karena setiap pegawai sudah mengetahui masing-masing pekerjaanya dan merupakan pekerjaan yang biasannya dikerjaakan sehari-hari sesuai dengan tupoksi yang ada, sehingga pegawai langsung bekerja tanpa harus menunggu perintah dari atasan.

Tabel 12. Deskripsi Jawaban Responden pada indikator Kemampuan

\begin{tabular}{|c|c|c|c|c|c|c|c|}
\hline \multirow[t]{3}{*}{ No } & \multirow[t]{3}{*}{ Pernyataan } & \multicolumn{5}{|c|}{ Likert } & \multirow[t]{3}{*}{ Total } \\
\hline & & STS & TS & $\mathrm{N}$ & $\mathrm{S}$ & SS & \\
\hline & & $\%$ & $\%$ & $\%$ & $\%$ & $\%$ & \\
\hline 1 & $\begin{array}{l}\text { Latar belakang pendidikan } \\
\text { sesuai dengan pekerjaan } \\
\text { yang ditugaskan }\end{array}$ & 0 & 0 & 6,3 & 50 & 43,8 & 100 \\
\hline 2 & $\begin{array}{l}\text { Bawahan memberikan } \\
\text { pelayanan tebaik kepada } \\
\text { masyarakat }\end{array}$ & 0 & 1,6 & 9,4 & 68,8 & 20,3 & 100 \\
\hline 3 & $\begin{array}{l}\text { Berusaha mengembangkan } \\
\text { keterampilan dalam } \\
\text { mengerjakan pekerjaan }\end{array}$ & 3,1 & 1,6 & 1,6 & 67,2 & 26,6 & 100 \\
\hline
\end{tabular}

Tabel 12 menunjukkan deskripsi jawaban responden pada indikator kemampuan. Pada pernyataan latar belakang pendidikan sesuai dengan pekerjaan yang ditugaskan, responden menjawab paling banyak setuju dengan jumlah 50\%, dikarenakan hampir semua latar belakang pendidikan pegawai sesuai dengan pekerjaan yang ditugaskan. Hal ini terjadi kepada kepala bidang perkebunan yang merupakan lulusan sarjana pertanian. Pada pernyataan bawahan memberikan pelayanan terbaik kepada masyarakat, responden paling banyak menjawab setuju dengan jumlah $68,8 \%$. Responden beranggapan setiap pegawai wajib memberikan pelayanan terbaik bagi masyarakat karena sesuai dengan tugas pokok dan fungsi dan diangkat dari jabatan yaitu melayani masyarakat. Pada pernyataan berusaha mengembangkan keterampilan dalam mengerjakan pekerjaan responden paling banyak menjawab setuju dengan jumlah $67,2 \%$, karena dengan mengembangkan keterampilan dapat menambah pengetahuan yang baru bagi pegawai serta menunjang tugas pokok instansi, sehingga pegawai akan lebih mudah menyelesaikan pekerjaan. Responden juga beranggapan hampir semua pegawai berusaha mengembangkan keterampilan mereka dengan cara mengikuti diklat dan belajar menguasai teknologi yakni komputer bagi pegawai yang kurang mampu menggunakannya. Kemampuan yang dimiliki pegawai menjadi faktor penting dalam meningkatkan kinerja jika pegawai dengan pendidikan yang memadai untuk jabatanya dan terampil dalam mengerjakan pekerjaan sehari-hari akan mudah mencapai kinerja yang maksimal.

Tabel 13. Deskripsi Jawaban Responden pada indikator Komunikasi

\begin{tabular}{|c|c|c|c|c|c|c|c|}
\hline \multirow[t]{3}{*}{ No } & \multirow[t]{3}{*}{ Pernyataan } & \multicolumn{5}{|c|}{ Likert } & \multirow[t]{3}{*}{ Total } \\
\hline & & STS & TS & $\mathrm{N}$ & $\mathrm{S}$ & SS & \\
\hline & & $\%$ & $\%$ & $\%$ & $\%$ & $\%$ & \\
\hline 1 & $\begin{array}{l}\text { Bawahan tidak ragu } \\
\text { bertanya kepada atasan } \\
\text { ketika mengalami kesulitan } \\
\text { dalam melaksanakan } \\
\text { pekerjaan }\end{array}$ & 0 & 3,1 & 6,3 & 42,2 & 48,4 & 100 \\
\hline 2 & $\begin{array}{l}\text { Setiap pegawai selalu } \\
\text { berdiskusi dan bertukar } \\
\text { informasi dengan sesama } \\
\text { rekan kerja }\end{array}$ & 0 & 0 & 9,4 & 50 & 40,6 & 100 \\
\hline 3 & $\begin{array}{l}\text { Pegawai selalu menghargai } \\
\text { dan menerima setiap } \\
\text { pendapat atau masukan dari } \\
\text { sesama rekan kerja }\end{array}$ & 0 & 3,1 & 0 & 46,9 & 50 & 100 \\
\hline
\end{tabular}

Tabel 13 menunjukkan deskripsi jawaban responden pada indikator komunikasi. Pada pernyataan bawahan tidak ragu bertanya kepada atasan ketika mengalami kesulitan dalam melaksanakan pekerjaan, responden paling banyak menjawab sangat setuju dengan jumlah 48,4\%. Hal ini dikarenakan setiap pegawai merasa tidak adanya batasan atau jarak antara atasan dan bawahan sehingga pegawai tidak ragu untuk bertanya kepada atasan ketika mengalami kesulitan dalam menyelesaikan pekerjaan. Pada pernyataan setiap pegawai selalu berdiskusi dan bertukar informasi dengan sesama rekan kerja, responden paling banyak menjawab setuju dengan jumlah $50 \%$. Hal ini karena dengan berdiskusi dan bertukar informasi akan menjalin komunikasi yang baik antar sesama rekan kerja yang akan membatu memberikan solusi dan masukan untuk kemajuan organisasi dan penyelesaian pekekerjaan di Dinas Pertanian Kabupaten Minahasa. Komunikasi berdiskusi dan bertukar informasi tidak hanya dilakukan dengan saling bertemu antara sesama pegawai tetapi juga dilakukan melalu via telepon, email, chatting dan lain-lain dengan mengikuti perkembangan teknologi yang ada. Pada pernyataan pegawai selalu menghargai dan menerima setiap 
pendapat atau masukan dari sesama rekan kerja responden paling banyak menjawab sangat setuju dengan jumlah 50\%, hal tersebut karena setiap pegawai berusaha untuk meciptakan hubungan yang baik dan kekompakan antara sesama rekan kerja. Hal ini disadari bahwa dalam bekerja pegawai akan saling membutuhkan karena sistem pekerjaan dirancang saling terkait antara bidang yang satu dan bidang yang lainnya. Komunikasi yang baik dan efektif akan meminimalisir terjandinya kesalahan sehingga meningkatkan kinerja pegawai.

\section{Uji Validitas dan Reliabilitas Kuesioner Penelitian}

\section{Uji Validitas Kuesioner Penelitian}

Uji validitas digunakan untuk menunjukkan tingkat kevalidan instrumen penelitian, artinya instrumen dapat digunakan untuk mengukur apa yang seharusnya diukur. Keputusan pada sebuah pernyataan dianngap valid apabila nilai signifikansinya kurang dari 0,05 . Berikut ini adalah hasil uji validitas dapat dilihat pada Tabel 14 .

Tabel 14. Uji Validitas Kuesioner Penelitian

\begin{tabular}{lcccc}
\hline Variabel & Pernyataan & $\begin{array}{c}\text { Nilai } \\
\text { Sig }\end{array}$ & Alpha & Keterangan \\
\hline Tunjangan & 1 & 0.000 & 0.05 & Valid \\
Kinerja (X) & 2 & 0.000 & 0.05 & Valid \\
& 3 & 0.000 & 0.05 & Valid \\
& 4 & 0.000 & 0.05 & Valid \\
Kinerja & 5 & 0.000 & 0.05 & Valid \\
Pegawai (Y) & 1 & 0.000 & 0.05 & Valid \\
& 2 & 0.000 & 0.05 & Valid \\
& 3 & 0.000 & 0.05 & Valid \\
& 4 & 0.000 & 0.05 & Valid \\
& 5 & 0.000 & 0.05 & Valid \\
& 6 & 0.000 & 0.05 & Valid \\
& 7 & 0.000 & 0.05 & Valid \\
& 8 & 0.000 & 0.05 & Valid \\
& 9 & 0.000 & 0.05 & Valid \\
& 10 & 0.000 & 0.05 & Valid \\
& 11 & 0.000 & 0.05 & Valid \\
& 12 & 0.012 & 0.05 & Valid \\
\hline
\end{tabular}

Sumber : Data olahan SPSS 20, 2017

Tabel 14 menunjukkan uji validitas kuesioner penelitian berdasarkan keseluruhan dari 17 item pernyataan yang diuji. Pernyataan pada variabel tunjangan kinerja (X) pernyataan $1,2,3,4,5$ memiliki nilai signifikan < alpha $(0,05)$ yang berarti setiap pernyataan pada variable tunjangan kinerja (X) dinyatakan valid (sah). Penyataan pada variable kinerja pegawai (Y) pernyataan 1,2 , $3,4,5,6,7,8,9,10,11,12$ memiliki nilai signifikan < alpha $(0,05)$ yang berarti setiap pernyataan pada variabel kinerja pegawai (Y) dinyatakan valid (sah).

\section{Uji Reliabilitas Kuesioner Penelitian}

Uji reliabilitas menunjukkan sejauh mana hasil suatu pengukuran dapat dipercaya atau menunjukkan bahwa insrtrumen yang digunakan memiliki konstitensi dalam hasil pengukuran. Dalam pengukuran reliabilitas menggunakan rumus Alpha Cronbach dengan bantuan SPSS versi 20. Adapun hasil uji reliabilitas yang telah dilakukan dalam penelitian ini adalah nilai Alpha Cronbach pada variabel tunjangan kinerja (X) sebesar 0,761 dan variabel kinerja pegawai (Y) sebesar 0,746 dapat dilihat pada Tabel 15.

Tabel 15. Uji Reliabilitas Kusioner Penelitian

\begin{tabular}{lccc}
\hline Variabel & $\begin{array}{c}\text { Cronbach } \\
\text { Alpha }\end{array}$ & Standard & Keterangan \\
\hline $\begin{array}{l}\text { Tunjangan } \\
\text { Kinerja } \\
(\mathrm{X})\end{array}$ & 0,761 & 0.6 & Reliabel \\
$\begin{array}{l}\text { Kinerja } \\
\text { Pegawai }\end{array}$ & 0,746 & 0.6 & Reliabel \\
$($ Y) & & & \\
\hline Sumber : Data olahan SPSS 20,2017 &
\end{tabular}

Sumber : Data olahan SPSS 20, 2017

Tabel 15 menunjukkan uji reliabilitas kuisioner penelitian. Penyataan pada variabel tunjangan kinerja $(\mathrm{X})$ pernyataan 1, 2, 3, 4, 5 memiliki nilai cronbach alpha > 0,6 yang berarti setiap pernyataan pada variabel tunjangan kinerja $(\mathrm{X})$ dinyatakan reliabel. Penyataan pada variable kinerja pegawai (Y) pernyataan $1,2,3,4,5,6,7,8,9,10,11,12$ memiliki cronbach alpha $>0,6$ yang berarti setiap pernyataan pada variabel kinerja pegawai (Y) dinyatakan reliabel. 


\section{Analisis Regresi Linier Sederhana}

Analisis regresi linier sederhana digunakan untuk mengetahui pengaruh variabel bebas terhadap variabel terikat. Model persamaan regresi linier sederhana dapat dilihat pada Tabel 16.

Tabel 16. Coefficient Model

\begin{tabular}{|c|c|c|c|c|c|}
\hline \multirow[t]{2}{*}{ Model } & \multicolumn{2}{|c|}{$\begin{array}{l}\text { Unstandardized } \\
\text { Coefficients }\end{array}$} & \multirow{2}{*}{$\begin{array}{c}\text { Standardized } \\
\text { Coefficients } \\
\text { Beta }\end{array}$} & \multirow[t]{2}{*}{$\mathrm{t}$} & \multirow[t]{2}{*}{ Sig. } \\
\hline & B & Std. Error & & & \\
\hline 1 (Constant) & 28,617 & 3,611 & & 7,924 & 0 \\
\hline $\begin{array}{l}\text { Tunjangan } \\
\text { Kinerja }\end{array}$ & 1,096 & 0,179 & 0,615 & 6,137 & 0 \\
\hline
\end{tabular}

Sumber : Data olahan SPSS 20, 2017

Persamaan regresi yang diperoleh adalah $\mathrm{Y}=28,617+1,096 \mathrm{X}$ menggambarkan bahwa variabel bebas (independen) Tunjangan Kinerja (X) dalam model regresi tersebut dapat dinyatakan jika satu variabel independen berubah sebesar 1 dan lainnya konstan, maka perubahan variabel terikat (dependen) Kinerja Pegawai (Y) adalah sebesar nilai koefisien (b) dari nilai variabel independen tersebut.

Nilai konstanta $(\alpha)$ sebesar 28,617 memberikan pengertian bahwa jika Tunjangan Kinerja (X) secara serempak atau bersama-sama tidak mengalami perubahan atau nilainya nol (0) maka besarnya Kinerja Pegawai (Y) nilainya positif sebesar 28,617 satuan. Nilai b yang merupakan koefisien regresi Tunjangan Kinerja (X) sebesar 1,096 yang artinya jika Tunjangan Kinerja (X) mengalami kenaikan satu satuan, maka tingkat Kinerja Pegawai (Y) mengalami peningkatan sebesar 1,096 satuan.

\section{Uji Hipotesis}

Pengujian hipotesis ini dilakukan menggunakan analisis regresi untuk mengetahui pengaruh variabel independen terhadap variabel dependen. Uji parsial (uji t) dilakukan untuk mengetahui pengaruh variabel bebas yaitu tunjangan kinerja terhadap variabel terikat yaitu kinerja pegawai.
Tabel 17. Uji Hipotesis

\begin{tabular}{lcc}
\hline Model & T & Sig. \\
\hline (Constant) & 7,924 & 0 \\
Tunjangan Kinerja & 6,137 & 0
\end{tabular}

Sumber : Data olahan SPSS 20, 2017

Tabel 17 menunjukkan pengujian hipotesis uji t. Hasil uji t menunjukkan bahwa nilai signifikansi tunjangan kinerja lebih kecil dari 0,05 . Tunjangan kinerja menunjukkan nilai t-hitung sebesar 6,137 dan koefisien regresi sebesar 1,096 serta nilai probabilitas 0,000 lebih kecil dari 0,05 yang berarti tunjangan kinerja berpengaruh signifikan terhadap kinerja pegawai, maka Ha diterima dan $\mathrm{H} 0$ ditolak.

\section{KESIMPULAN DAN SARAN}

\section{Kesimpulan}

Dari hasil penelitian dan pembahasan yang telah dilakukan, maka dapat ditarik kesimpulan, Tunjangan kinerja mempunyai pengaruh positif dan signifikan terhadap kinerja pegawai di Dinas Pertanian Kabupaten Minahasa, hasil penelitian menunjukkan dengan adanya tunjangan kinerja pegawai akan termotivasi bekerja dengan maksimal sehingga berpengaruh terhadap peningkatan kinerja pegawai pada Dinas Pertanian Kabupaten Minahasa.

\section{Saran}

Berdasarkan hasil penelitian penulis memberi saran sebagai berikut:

1. Mengingat Tunjangan kineja memiliki pengaruh serta memberikan kontribusi yang cukup besar terhadap Kinerja pegawai. Diharapkan Dinas Pertanian Kabupaten Minahasa memperhatikan faktor Tunjangan Kinerja.

2. Dalam penelitian ini yang diteliti hanya terbatas pada pengaruh Tunjangan Kinerja terhadap Kinerja Pegawai sedangkan faktorfaktor lain yang berpengaruh terhadap kinerja pegawai belum diungkapkan, semoga pada penelitian selanjutnya dapat membahas faktor-faktor lain yang belum diteliti dalam penelitian ini. 


\section{DAFTAR PUSTAKA}

Anonim. 2010. Peraturan Pemerintah Nomor 53 tentang Disiplin Pegawai Negeri Sipil. Jakarta.

2011. Peraturan Menteri Pendayagunaan Aparatur Negara dan Reformasi Birokrasi Nomor 63 tentang Pedoman Penataan Sistem Tunjangan Kinerja Pegawai Negeri.

Arikunto. 2006. Prosedur Penelitian Suatu Pendekatan Praktek. PT. Rineka Cipta. Jakarta.

Fajar, Siti Al. 2010. Manajemen Sumber Daya Manusia: Sebagai Dasar Meraih Keunggulan Bersaing. UPP STIM YKPN. Yogyakarta.

Ghozali, Imam. 2011. Aplikasi Analisis Multivariate Dengan Program IBM SPSS 17, Cetakan Kelima, Semarang: Badan Penerbit Universitas Diponegoro.

Handoko. 2001. Manajemen Personalia dan Sumberdaya Manusia, Edisi Kedua. BPFE, Yogyakarta.

Hesti Risma Piani. 2015 Pengaruh Tambahan Penghasilan Pegawai Negeri Sipil (TPPNS) Terhadap Kinerja Pegawai Eselon III Dan IV Di Dinas Kesehatan Kota Serang. Universitas Sultan Ageng Tirtayasa. Serang.

Irawan, Andi. 2015. Faktor-Faktor yang Mempengaruhi Kinerja Pegawai Negeri Sipil di Direktorat Jenderal Pendidikan Tinggi. Bogor: Institut Pertanian Bogor.

Kadarisman, M. 2012. Manajemen Kompensasi. Rajawali Pers. Jakarta.

Lifana, Pramono Dan Sutrisno 2013 Pengaruh Insentif Dan Tunjangan Terhadap Kinerja Karyawan Pada PT. BPR Wilis Putra Utama Banyuwangi. Universitas Jember.
Mangkunegara, A. A, Prabu. 2009. Evaluasi Kinerja Sumber Daya Manusia. Refika Aditama. Bandung.

Mondy, R. Wayne and Martocchio, Joseph J. 2016. Human Rosource Management (14th edition). England: Pearson Education Limited.

Pangabean, Mutiara S. 2002. Manajemen Sumber Daya Manusia. Cetakan Pertama. Ghalia Indonesia. Jakarta.

Pasolog H. 2012. Metode Penelitian Administrasi Publik. Alfabeta. Bandung.

Rivai 2004. Manajemen Sumber daya Manusia. Rajawali Pers. Jakarta.

2009. Manajemen Sumber daya Manusia. Raja Grafindo Persada Jakarta.

Sedarmayanti. 2001 Manajemen sumber daya manusia dan produktifitas kerja. CV. Mandar Maju. Bandung.

Siagian, Sondang. 2007. Manajemen Sumber Daya Manusia. PT. Bumi Aksara. Jakarta.

Simamora, H. 2004. Manajemen Sumber Daya Manusia. STIE YPKN. Yogyakarta.

Simanjuntak, J. 2005. Manajemen dan Evaluasi Kinerja. FE UI. Jakarta.

Sugiyono. 2008. Metode Penelitian Bisnis. Alfabeta. Bandung.

2011. Metode Penelitian Kuantitatif, Kualitatif dan R\&D. Afabeta. Bandung.

Sutrisno, Edy. 2010. Manajemen Sumber Daya Manusia. PT Prenada Media Group. Jakarta. 2010. Manajemen Sumber Daya Manusia. Kencana. Jakarta. 